\title{
片側エネルギー減衰を受けた擬似ベル状態のエンタングルメント特性
}

\author{
非会員 山本 竜太郎* 非会員 服部 誠司** \\ 正員 白田 毅** 正員 内匠逸*
}

Entanglement of Formation of a Quasi-Bell State with Non-Symmetric Loss

Ryutaro Yamamoto*, Non-member, Seiji Hattori**, Non-member, Tsuyoshi Sasaki Usuda**, Member, Ichi Takumi*, Member

Entanglement of formation (EoF) for a quasi-Bell state degraded by an attenuation channel is computed. As a result, it is clarified that EoF for a quasi-Bell state is greater than that for the Bell states.

キーワード : エンタングルメント, Entanglement of formation, 擬似ベル状態, 減衰通信路

Keywords: entanglement, Entanglement of formation, quasi-Bell state, attenuation channel

1. はじめに

エンタングルメントは, 量子情報理論に特有の概念であ り，エンタングルメント援助による古典情報伝送（あるい は量子デンスコーディング) のように , 情報機能を高めるリ ソースとして位置づけられる。応用を考えた場合，完全に エンタングルした状態の利用が望ましいが , 近年 , 光のコ ヒーレント状態のような非直交状態によって, エンタングル メントが最大の状態を構成できることが示された ${ }^{(1)}$ 。光に おいては, 単一光子状態の生成技術が必要とされる直交状 態に比べ, 非直交状態は作りやすいという利点があるため, この発見は非常に有益なものといえる。さて, 実際に量子通 信などに用いる場合は, エンタングルメントに対する通信

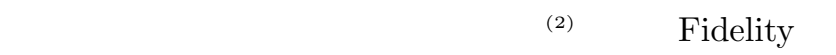
用い, コヒーレント状態による擬似ベル状態のエンタング ルメントを考察をしている。しかし , Fidelity はエンタング ルメント測度の下限に対応するのみで, エンタングルメン ト炎のものを表していない。本稿では, エンタングルメント 測度のひとつである, Entanglement of Formation ${ }^{(3)}$ (以 下, EoF と呼引゙）を用い, 擬似ベル状態のエンタングルメ ントの減衰による劣化特性を考察する。

\section{2. コヒーレント状態による擬似ベル状態}

コヒーレント状態はレーザー光で近似的に実現できる光 の量子状態で, もつとも安定した光の量子状態といわれて いる ${ }^{(5)}$ 。一般に, コヒーレント状態は非直交で, コヒーレ ント状態が直交するには, 無限のパワーが必要となる。さ て, コヒーレント状態による擬似ベル状態には, 樣々なも のがあるが，ここでは，特に完全エンタングルメント状態

* 名古屋工業大学, 名古屋市昭和区御器所町

Nagoya Institute of Technology, Nagoya 466-8555, Japan ** 愛知県立大学, 愛知県長久手町熊張

Aichi Prefectural University, Aichi 480-1198, Japan
となる以下の $\left|\Psi_{\mathrm{AB}}\right\rangle$ に注目する。

$$
\left|\Psi_{\mathrm{AB}}\right\rangle=h_{4}\left(|\alpha\rangle_{\mathrm{A}}|\beta\rangle_{\mathrm{B}}-|-\alpha\rangle_{\mathrm{A}}|-\beta\rangle_{\mathrm{B}}\right) \cdots \cdots(1)
$$

ここで, $\{\alpha,-\alpha\},\{\beta,-\beta\}$ は, $\mathrm{A}, \mathrm{B}$ の各部分系におけるコ ヒーレント状態の振幅を表す。また,$h_{4}=1 / \sqrt{2\left(1-\kappa_{\mathrm{A}} \kappa_{\mathrm{B}}\right)}$, $\kappa_{\mathrm{A}}=\langle\alpha \mid-\alpha\rangle, \kappa_{\mathrm{B}}=\langle\beta \mid-\beta\rangle$ である。以降， $\alpha$ と $\beta$ は非 負の実数であると仮定する。

3. エンタングルメントに対する減衰の影響

〈3 1 減衰のモデル 本研究では, エンタングルメ ント援助による古典情報伝送への応用を想定し，送信者は， 系 $\mathrm{A}$ を保持し, 系 $\mathrm{B}$ をエネルギー減衰通信路を通して受 信者へ伝送する，片側減衰モデルを扱う。 $\eta$ を減衰通信路 における透過率 $(0 \leq \eta \leq 1)$ とすれば，A，B の混合状態 を表す統計作用素 $\rho_{\mathrm{AB}}$ は, 結果として ,

$$
\begin{aligned}
\rho_{\mathrm{AB}}= & \left(\tilde{h}_{4}\right)^{2}\left(|\alpha\rangle_{\mathrm{A}}\langle\alpha|\otimes| \sqrt{\eta} \beta\rangle_{\mathrm{B}}\langle\sqrt{\eta} \beta|\right. \\
& -L|\alpha\rangle_{\mathrm{A}}\langle-\alpha|\otimes| \sqrt{\eta} \beta\rangle_{\mathrm{B}}\langle-\sqrt{\eta} \beta| \\
& -L|-\alpha\rangle_{\mathrm{A}}\langle\alpha|\otimes|-\sqrt{\eta} \beta\rangle_{\mathrm{B}}\langle\sqrt{\eta} \beta| \\
& \left.+|-\alpha\rangle_{\mathrm{A}}\langle-\alpha|\otimes|-\sqrt{\eta} \beta\rangle_{\mathrm{B}}\langle-\sqrt{\eta} \beta|\right) \cdots
\end{aligned}
$$

となる。ここで，

$$
\begin{aligned}
& \tilde{h}_{4}=1 / \sqrt{2\left(1-L \kappa_{\mathrm{A}} \kappa_{\mathrm{B}}^{\prime}\right)}, \quad \kappa_{\mathrm{B}}^{\prime}=\langle\sqrt{\eta} \beta \mid-\sqrt{\eta} \beta\rangle \\
& L=\langle\sqrt{1-\eta} \beta \mid-\sqrt{1-\eta} \beta\rangle=\exp \left[-2(1-\eta)|\beta|^{2}\right]
\end{aligned}
$$

〈3. 2〉 EoF の計算 まず, 準備として, 系 A に対 し, 2 つの直交ベクトル $|1\rangle=|\alpha\rangle, \quad|0\rangle=(|-\alpha\rangle-$ $\left.\kappa_{\mathrm{A}}|\alpha\rangle\right) / \sqrt{1-\kappa_{\mathrm{A}}^{2}}$ を導入する。同樣に系 $\mathrm{B}$ に対しても直 交べクトル $|1\rangle,|0\rangle$ を導入することができる。コヒーレント 状態は，一般には，無限次元の光系に属するが， $\rho_{\mathrm{AB}}$ のサ ポートが, 上記の直交ベクトルで張られる 4 次元の部分空 間であることに注意すると， $\rho_{\mathrm{AB}}$ の $\mathrm{EoF}$ の計算には，混 合 2-qubit 状態に対する公式 ${ }^{(4)}$ が適用でき， 


$$
E\left(\rho_{\mathrm{AB}}\right)=h\left(\frac{1}{2}+\frac{1}{2} \sqrt{1-C^{2}}\right)
$$

となる。ただし, $h$ は 2 値エントロピー関数 $h(x)=$ $-x \log _{2} x-(1-x) \log _{2}(1-x)$ であり ,

$$
C=\max \left\{0,2 \lambda_{\max }-\operatorname{Tr} R\right\}
$$

$\lambda_{\max }$ は $R=\sqrt{\sqrt{\rho_{\mathrm{AB}}} \tilde{\rho}_{\mathrm{AB}} \sqrt{\rho_{\mathrm{AB}}}}$ の固有値の最大值 , $\tilde{\rho}_{A B}=$ $\sum_{i, j}\left|e_{i}\right\rangle\left\langle e_{j}\left|\rho_{\mathrm{AB}}\right| e_{i}\right\rangle\left\langle e_{j}\left|,\left\{\left|e_{i}\right\rangle \mid i=1,2,3,4\right\}\right.\right.$ は, 直交べク トル $|1\rangle,|0\rangle$ に基づく 4 つのベル状態の集合で , マジック基 底と呼ばれる。

〈3. 3〉 エンタングルメント特性ＥoF とコヒーレン 卜状態の振幅 $\alpha$ と $\beta$ との関係を考察するため, $\eta=0.5$ の 場合の $\alpha$ と $\beta$ に対する $\mathrm{EoF}$ の等高線グラフを図 1 に示す。 等高線グラフは色が白いほど $\mathrm{EoF}$ の值が大きく，黑に近い ほど EoF が小さいことを表している。

図 1 より, 振幅が小さく , かつ $\alpha \approx \beta$ のとき , $\mathrm{EoF}$ が大

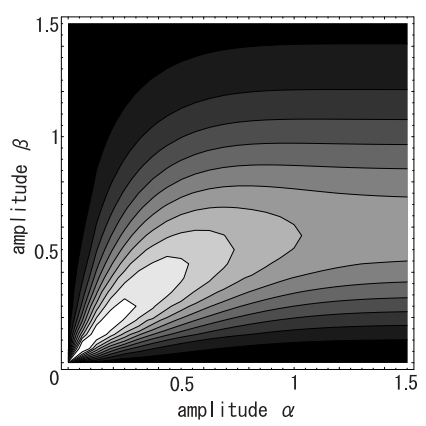

図 1 EoF as a function of amplitudes $\alpha$ and $\beta$.

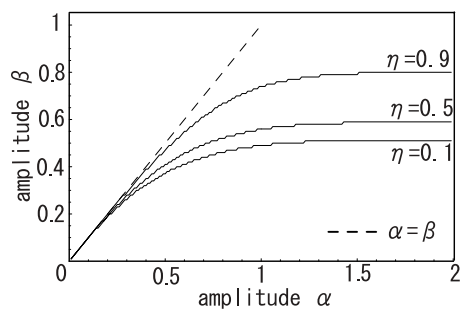

図 2 Pair of amplitudes $\alpha$ and $\beta$ with which EoF is maximized.

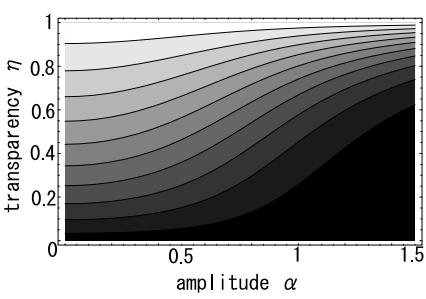

図 3 EoF with respect to amplitude and transparency.

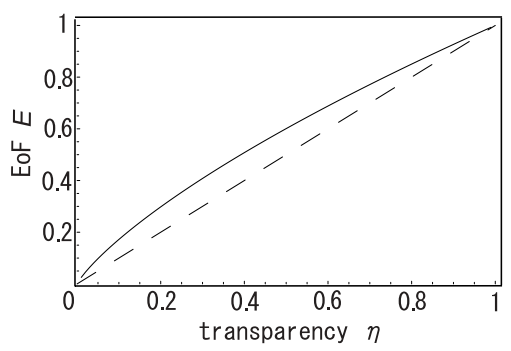

図 4 EoF as a function of transparency $\eta$.
きいことがわかる。これは，振幅が大きいと少しの減衰で 量子性が失われてしまうことに対応していると考えられる。 透過率 $\eta$ が異なっても，定性的には図 1 と同樣になる。図 2 は , $\mathrm{EoF}$ を最大にする $\alpha$ と $\beta$ を示したものである。参考 のため， $\alpha=\beta$ を示す破線も示している。図 2 より，振幅 が小さい場合， $\alpha \approx \beta$ のとき $\mathrm{EoF}$ は最大となる。また，振 幅 $\alpha$ を大きくしていった場合， $\beta$ は $\eta$ の值に応じてある值 に収束することがわかる。これは, エンタングルメントは 系 A と B の量子相関であるため, 両系のバランスがとれ ていた方が大きく，減衰がなければ $\beta \approx \alpha$ がよいが, 振幅 が小さい方が減衰の影響を受けにくいことから，系 B に減 衰があるときは $\beta<\alpha$ とした方が良いことを表し，また， $\alpha$ がある程度大きければ，系 $\mathrm{A}$ の方はほぼ直交とみなせ， $\beta$ の最適値は一定値に落ち着くためと理解できる。

図 3 は， $\alpha=\beta$ とし，振幅と透過率に対する $\mathrm{EoF}$ の值を 等高線グラフで表したものである。図 3 より， $\alpha$ が大きい とき, 透過率が 1 に近くないと， EoF は急激に小さくなる。 また , $\alpha$ を小さくするほど , EoF は大きくなるが, $\alpha<0.1$ では, EoF はほとんど変わらない。

図 4 は, 比較のため, ベル状態と擬似ベル状態について 透過率に対する EoF の值を表したものである。破線は単一 光子によるベル状態の $\mathrm{EoF} て ゙, ~ \eta$ に比例している。実線は 擬似ベル状態の EoF を表しており，これまでの結果から， 振幅を $\alpha=\beta=0.01$ としている。図 4 より, ベル状態に 比べ, 擬似べル状態の方が $\mathrm{EoF}$ が大きいことがわかる。し たがって, 適切な振幅の擬似ベル状態は単一光子によるべ ル状態より通信路の影響を受けにくく，エンタングルメン トの劣化が小さいといえる。

4. まとめ

コヒーレント状態による擬似ベル状態に対し，エンタン グルしたペアの片方のみを減衰させたときの, EoF の特性 を考察した。結果として , コヒーレント状態の振幅は小さ いほどよく，振幅が大きい場合は，透過率が 1 に近くない と EoF の值は急激に小さくなってしまうことがわかった。 また, 単一光子によるベル状態に比べ, 擬似ベル状態の方 が通信路の影響を受けにくいということか確認された。よっ て, 文献 ${ }^{(2)}$ の Fidelity を用いた考察は, エンタングルメ ントの強さという意味でも, 定性的には正しい結果を示し ていたといえる。

本研究の一部は, 総務省の「戦略的情報通信研究開発推 進制度」による研究成果である。

\section{文献}

(1) O. Hirota and M. Sasaki: "Entangled states based on nonorthogonal state", Proc. QCM\&C2000, pp.359-366 (2001)

( 2 ) O. Hirota, M. Sohma, and K. Kato: "Quasi bell states; Generation and application to entanglement assisted communication", Proc. Photonics-2002 (2002)

( 3 ) C.H. Bennett, et al.: "Mixed-state entanglement and quantum error correction", Phys. Rev. A54, pp.3824-3851 (1996)

(4) S. Hill and W.K. Wootters: "Entanglement of a pair of quantum bits", Phys. Rev. Lett. 78, pp.5022-5025 (1997)

（5）氏原紀公 訳：「量子光学の考え方」, 内田老鶴圃 (1989)

（6）木村達也 訳 : 「量子コンピュータと量子通信」, オーム社 (2005) 